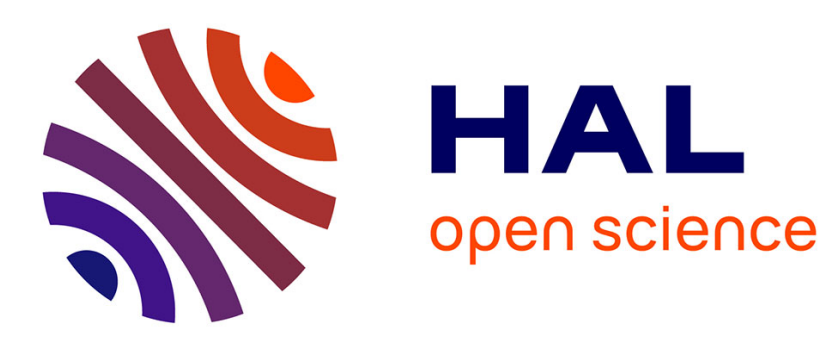

\title{
Untapped Riches of Meso-Level Applications in Multilevel Entrepreneurship Mechanisms
}

\author{
Phillip H. Kim, Karl Wennberg, Grégoire Croidieu
}

\section{To cite this version:}

Phillip H. Kim, Karl Wennberg, Grégoire Croidieu. Untapped Riches of Meso-Level Applications in Multilevel Entrepreneurship Mechanisms. Academy of Management Perspectives, 2016, 30 (3), 273-291 p. hal-02276717

\section{HAL Id: hal-02276717 https://hal.science/hal-02276717}

Submitted on 3 Sep 2019

HAL is a multi-disciplinary open access archive for the deposit and dissemination of scientific research documents, whether they are published or not. The documents may come from teaching and research institutions in France or abroad, or from public or private research centers.
L'archive ouverte pluridisciplinaire HAL, est destinée au dépôt et à la diffusion de documents scientifiques de niveau recherche, publiés ou non, émanant des établissements d'enseignement et de recherche français ou étrangers, des laboratoires publics ou privés. 


\title{
$\begin{array}{lllllllll}S & \mathrm{Y} & \mathrm{M} & \mathrm{P} & \mathrm{O} & \mathrm{S} & \mathrm{I} & \mathrm{U} & \mathrm{M}\end{array}$
}

\section{UNTAPPED RICHES OF MESO-LEVEL APPLICATIONS IN MULTILEVEL ENTREPRENEURSHIP MECHANISMS}

\author{
PHILLIP H. KIM \\ Babson College \\ KARL WENNBERG \\ Linköping University \\ GRÉGOIRE CROIDIEU \\ Grenoble Ecole de Management
}

\begin{abstract}
Entrepreneurial action is embedded within a variety of complex social structures, not all of which can be as easily defined or measured as macro-institutional or micro-individual characteristics. Nonetheless, these multilayered structures collectively hold rich insightsbefore now underexamined-into the actual causal mechanisms that affect entrepreneurial actions and outcomes. To address this problem, we call on researchers to broaden their levels of analysis and direct their focus to meso-level structures. Although meso-level social structures are widely studied independently, these intermediate levels are seldom integrated into existing multilevel models. We argue that meso-level structures offer untapped riches for enhancing multilevel entrepreneurial mechanisms and discuss how social groups, associations, and other collectives operating at a meso level can play a more distinct, integrative role between the two ends of the institutional spectrum. To provide practical guidance for pursuing such investigations, we adapt Coleman's bathtub model to form a robust framework that integrates micro, meso, and macro levels of analysis. Our framework helps alleviate the shortcomings produced by an overdependence on either solely macro- or micro-level entrepreneurial mechanisms and offers fresh insights, as the intermediate level is more deeply integrated into this new framework.
\end{abstract}

"Diamonds! What do you want with diamonds?"

"Why, I wish to be immensely rich."

"Well, then, go along and find them. That is all you have to do; go and find them, and then you have them."

$$
\text { Russell Conwell, Acres of Diamonds (1890) }
$$

We appreciate the guidance from our reviewers and editor Mike Wright and comments from Martin Andersson, Steve Bradley, Nikki Bown, Johan Eklund, Peter Hedström, Tomas Karlsson, Peter Klein, Barbara Larrañeta, Arnis Souka, Johan Wiklund, Petri Ylikoski, and seminar participants at the Institute for Analytical Sociology (IAS) at Linköping University, Syracuse University, and Universidad Pablo Olavide. Karl Wennberg gratefully acknowledges financial support from the Swedish Research Council (340-2013-5460), Riksbankens Jubileumsfond (M12-0301:1), and the Ragnar Söderberg Foundation. Please direct correspondence to the first author.
In one of the canonical essays for entrepreneurship research, Stinchcombe (1965) wrote about the "organizing capacity" of societies-that country-level conditions influence the extent to which societies foster or hinder the formation of new organizations. Advancements in multilevel entrepreneurship research have brought Stinchcombe's principle to life. Using North's (1990) classic definition of formal institutions_-"rules of the game"-many scholars have examined how laws, regulations, tax policies, and other country-level characteristics influence entrepreneurial action - the activities and behaviors required to launch, sustain, and grow new businesses (Autio, Dahlander, \& Frederiksen, 2013; Carter, Gartner, \& Reynolds, 1996; McMullen \& Shepherd, 2006). Most of these studies explicitly link countrylevel (macro) characteristics with individual-level 
(micro) outcomes to account for variance at both country and individual levels (e.g., Djankov, Ganser, McLiesh, Ramalho, \& Shleifer, 2010; Lee, Yamakawa, Peng, \& Barney, 2011). With public availability of large-sample datasets such as the Global Entrepreneurship Monitor (GEM) and the World Bank's Doing Business report, researchers can employ multilevel modeling techniques to analyze contextual effects on individual outcomes and compare these findings across countries (e.g., Autio, Pathak, \& Wennberg, 2013). Typically, these multilevel studies are conducted with a simple, two-level top-down mechanism in mind: that macro-level country characteristics influence individual-level entrepreneurial outcomes.

Despite the widespread appeal of multilevel research designs, there are limitations to this two-level analytical approach. Most notably, the distance between macro and micro levels is often large enough to dilute a two-level model's explanatory power. We highlight two empirical puzzles to illustrate these limitations and demonstrate why integrating a third level — the meso level—is beneficial for deepening our understanding of entrepreneurial outcomes. The first empirical puzzle is this: Why do some countries with weak national institutions have robust individual start-up rates, while other countries with strong national institutions have some of the lowest rates of start-up activity in the world? Research using the GEM data confirms significant cross-country variation in start-up rates. However, measures of macro-level institutional quality are only modestly correlated with these start-up rates and cannot fully account for this variation (e.g., Levie, Autio, Acs, \& Hart, 2014).

A second empirical puzzle is this: Why are only some entrepreneurs able to collectively navigate adverse regulatory conditions and bring their products and services to market? For instance, during the last several decades in China, entrepreneurs launching private enterprises have managed to navigate through unfavorable legal systems and hostile operating environments and collectively establish legitimate industrial sectors recognized by the national government (Nee \& Opper, 2012). This runs contrary to predictions based on classical theories that weak macro-institutional conditions should stymie entrepreneurial efforts.

Institutional change can also occur through intermediate levels, so integrating the meso level-currently underutilized in most multilevel research-may offer important clues for solving these empirical puzzles. For example, incorporating how individuals establish and leverage social ties in voluntary associations and other collectives would provide a meso-level mechanism to address some of the unexplained country- and individual-level differences in these examples.

An overreliance on simple two-level macro-micro research designs also exposes these arguments to two analytical traps: the ecological fallacy and the disaggregation bias. The ecological fallacy occurs when institutional influences on entrepreneurial action are attributed to the individual level, based only on macro-to-macro associations (Peterson, Arregle, \& Martin, 2012). While macro-to-macro analyses, such as country-level studies, are beneficial if inferences remain at the macro level, they are misleading if inferences about entrepreneurial outcomes are attributed to lower levels of analysis. For example, macro-to-macro analyses can mask how variance in institutional conditions influences individuals (or other lower levels of analysis), and how aggregated individual responses to institutions affect macrolevel outcomes (King, 2013). In both situations, these analyses underemphasize the heterogeneity among actors at lower levels and do not fully address how variance affects inferences at higher levels. Thus, even if two countries exhibit similar start-up rates, it could be misleading to conclude that individuals in both countries also approach entrepreneurship in similar ways. Alternatively, disaggregation bias occurs when causal mechanisms are reduced to microor individual-level explanations (Jepperson \& Meyer, 2011; McAdam, Tarrow, \& Tilly, 2001). Micro-level entrepreneurship research is particularly prone to the disaggregation bias because many published studies focus on individual-level outcomes.

We argue that to build stronger theory from multilevel research designs, empirical models ought to integrate meso-level constructs to improve their effectiveness in unraveling these empirical puzzles and avoid the analytical traps we discussed. The meso level represents a third, intermediate level of analysis between the more common macro (higher) and micro (lower) levels (Börner et al., 2010; Liljenström \& Svedin, 2005). This third level serves as a bridge between higher and lower levels of analysis. By definition, the meso level is embedded within this macro-micro hierarchy. Within current entrepreneurial research, meso-level influences have remained present in all research contexts but have rarely been sought out or integrated into multilevel analyses, thus limiting the richness and depth of insight these studies can provide.

In this article, we advocate for the closer integration of social groups as a meso-level structure into 
multilevel models of entrepreneurial action. Social groups represent "a collection of individuals who have relations to one another that make them interdependent to some significant degree" (Cartwright \& Zander, 1968, p. 46). People are social beings, embedded in formal and informal social structures (Granovetter, 1985). Entrepreneurs are no different. The businesses they attempt to form do not operate in a vacuum, but inhabit open environments and are susceptible to influences from structures at higher levels of analysis (Stinchcombe, 1991). For example, entrepreneurs often join networking groups, seek advice from mentors, or work collaboratively with others to build their organizations. All of these social groups are embedded in a broader social environment and help bridge macro-level influences and micro-level action.

While existing multilevel research attempts to answer questions about entrepreneurial outcomes (the dependent variables), very few studies have brought social groups explicitly into their multilevel models of entrepreneurial action (e.g., as independent variables), despite the extensive effort scholars have made to understand social groups in the entrepreneurial context (Ruef, 2010). According to Shane and Venkataraman (2000, p. 218), "It is improbable that entrepreneurship can be explained solely by reference to a characteristic of certain people independent of the situations in which they find themselves." In this vein, conducting multilevel studies involving countries and individuals is an initial step toward contextualizing entrepreneurship, but deeper investigations are needed to capture the multifaceted environments in which business formation occurs.

Our main objective is to demonstrate the benefits of integrating social group, meso-level structures more explicitly into institutional analyses of entrepreneurship. We argue that these insights are untapped riches capable of providing a more comprehensive understanding of contextual influences in entrepreneurial mechanisms. Mechanisms are explanations that convey theoretical causation between two concepts; they are the arrows that link concepts together within and across levels of analysis. In multilevel scenarios, these mechanisms are often affected by the macro-micro problem, where "observations are not on the system as a whole, but on some part of it" (Coleman, 1987, p. 153), as illustrated by the lack of integration between the social group and institutional streams in entrepreneurship. By introducing the meso level to both macro- and micro-level analyses, our goal is to increase exposure to the multilevel combinations and trade-offs that can help us better understand social systems and their constituent parts. A socialsystems perspective assumes that actors do not behave autonomously but are embedded in a "relational system of interaction between individuals and collectivities" (Kroeber \& Parsons, 1958, p. 583). By underscoring a systemic view, we argue that entrepreneurial action needs to be studied within a broader context and that an exclusive focus on macro-level entities or micro-level individuals ought to be avoided (McMullen \& Shepherd, 2006). We also illustrate the variety of bi-directional mechanisms (both top-down and bottom-up linkages) that can be investigated with the integration of the meso level. At stake is developing a clearer, more comprehensive understanding of the appropriate influences driving entrepreneurship.

We contribute the following insights to the multilevel entrepreneurship research literature. We aim to harmonize arguments that emphasize the influence of social structures (whether formal or informal) while also seriously considering the role of individual-level characteristics. With this purpose in mind, we offer a framework for better contextualizing entrepreneurial activity in society, ${ }^{1}$ not by fully reviewing and contrasting these two research streams but by offering an integrative, multilevel framework that enhances each of their complementarities. We apply the "bathtub" model, originally introduced by Coleman (1990) and refined by Hedström and Swedberg (1998), as an organizing framework to expose shortcomings among the bi-directional, multilevel pathways typically addressed in current research. We also promote the promise of pursuing social-group mesolevel entrepreneurship research as a potential mediator or moderator between macro- and micro-level aspects of entrepreneurship. Besides the commonly studied top-down mechanisms (e.g., country influences on individual outcomes), we also aim to spur on new arguments about bottom-up mechanisms where micro-level actions or characteristics are mediated or moderated by meso-level social groups, which eventually go on to influence macro-level institutions. Last, our work adds precision to the entrepreneurial mechanisms employed in existing research by articulating how and why entrepreneurship matters within the broader social context. We build on the insights offered by other scholars who have also argued for more explicit linkages between individual entrepreneurial action and the broader social contexts in which it occurs (Aldrich, 2012; Baker, Gedajlovic, \&

\footnotetext{
1 "Entrepreneurial activity" refers to macro-level studies of entrepreneurship rates across regions (Sorenson \& Audia, 2000) or countries (Zahra \& Wright, 2011).
} 
Lubatkin, 2005; Ruef \& Lounsbury, 2007; Sine \& David, 2010; Tolbert, David, \& Sine, 2011; Welter, 2011).

\section{PRELIMINARIES}

To accomplish our objectives, we first present a rationale for why it is important to study entrepreneurial mechanisms within a multilevel context. We then introduce our case for why a relational meso-level approach is needed and how it can be integrated into the bathtub model. We propose two applications explicitly integrating the meso level into macro- and micro-level analyses: one based on top-down mechanisms and another based on bottomup arguments. Finally, we take stock of the existing literature related to these two applications and offer practical advice for how scholars can apply integrated meso-level mechanisms in future research to yield richer insights about the totality of the entrepreneurial phenomenon.

Before fleshing out the main components of our theory, we define our framework's key concepts. Our ultimate aim is to improve our understanding of how and why certain institutional characteristics influence entrepreneurial action, and how such action may eventually go on to affect the institutions themselves (Li, Feng, \& Jiang, 2006; Tolbert et al., 2011). While we refer to our dependent variable in its generic form (“entrepreneurial action”), we posit that our proposed arguments can be adapted to address specific outcomes associated with this generic form. One of the major independent variables addressed in our article is the role of formal institutions. Economic research views institutions from a largely functionalist standpoint, as noted in the terminology of "institutional setup" (Andersson \& Henrekson, 2014) or "institutional design" (Goodin, 1998; Williamson, 1973). Formal institutions are intentionally devised "rules of the game" (North, 1990; Williamson, 1998)—socially constructed regulations that govern market transactions in societies.

We also devote considerable attention to social groups at the meso level as a bridge between macroand micro-level arguments prevalent in existing multilevel research in entrepreneurship. Recall that social groups represent collectives of individuals in interdependent relationships (Cartwright \& Zander, 1968). Clearly, social groups-whether as founding teams, kinship networks, mentoring groups, or other types of associations-matter for entrepreneurial action (Eesley \& Wang, 2014; Parker, 2008; Portes \& Sensenbrenner, 1993; Rotger, Gørtz, \& Storey, 2012). The emphasis on social groups is not surprising:
About $85 \%$ of start-up founders in the United States involve other individuals-either as co-owners or supporters-in their start-up efforts (Ruef, 2010). Some of these individuals may be family members; others may be friends or colleagues (Kim, Longest, \& Aldrich, 2013).

Practitioners stress the relational aspects of founding efforts, as experienced entrepreneurs often advise their novice counterparts to start ventures in thoughtfully constructed teams (Mullins, 2006). Several important publications have appeared in recent years testifying to the importance of such collectives in entrepreneurship. Studies on entrepreneurial groups (Ruef, 2010; Ruef, Aldrich, \& Carter, 2003), analyses of top management teams in high-growth start-ups (e.g., Beckman \& Burton, 2008; Klotz, Hmieleski, Bradley, \& Busenitz, 2014), and investigations into the dilemmas of ownership dynamics (Wasserman, 2012) all demonstrate the breadth of insights derived from founding teamrelated issues. Moreover, inquiries on tie formation among Indian entrepreneurs (Vissa, 2010, 2011), research on exposure to "good ideas" (Burt, 2004), and work on strong and weak ties (Jack, 2005) further reveal key facets of relationship structures and their bearing on entrepreneurial outcomes. More generally, these insights represent important mesolevel components of entrepreneurial mechanisms and their potential influence on micro-level outcomes. In the following section, we demonstrate how mechanism-based research that integrates meso-level actors such as social groups reduces the likelihood of getting ensnared in analytical traps associated with macro-micro multilevel designs.

\section{WHY STUDY ENTREPRENEURSHIP MECHANISMS?}

Without an integrative multilevel framework, entrepreneurship research involving macro and micro dimensions is prone to the two analytical traps we discussed above: the ecological fallacy and the disaggregation bias. Due to the pervasiveness of these two analytical traps, finding universal causal laws governing the association between institutions and entrepreneurship can be elusive and susceptible to both measurement errors and overgeneralization of statistical causal claims. We argue that conclusions drawn from studies that do not incorporate intermediate levels of analysis may be misleading because the interpretations are based on incorrect inferences of macro-to-macro associations. This can occur by failing to account for any heterogeneity in individual 
responses to macro institutions (a consequence of the ecological fallacy) or by conflating agency with actors' motivations (a consequence of disaggregation bias) (Campbell, 2004). Instead, we see opportunities for an integrative framework that enables the full use of multilevel mechanisms to explain how and why individual action is interdependent on, rather than independent from, other individuals' action (e.g., Hedström \& Ylikoski, 2010; Weber, 2006).

As Stinchcombe (1991) articulated, causal mechanisms often work at distinctly different levels of analysis than the predictions they explain. In research examining institutional effects on entrepreneurship, it is common to find the emphasis mainly on the direct impact of institutions on entrepreneurial action, but investigations of potential moderators or mediators between these two constructs are rare. This is not surprising, given both the lack of theoretical clarity in the mechanisms operating between higher-level institutions and lower-level entrepreneurial outcomes and the empirical convenience of using large-sample data sets. While we benefit from the insights gained from pursuing such investigations, we still lack comprehensive multilevel frameworks best suited for theorization on entrepreneurial mechanisms.

Studying entrepreneurial mechanisms allows for a more precise articulation of the contexts that drive entrepreneurial action, as well as which actions can transform these contexts. Recall that mechanisms are explanations that convey theoretical causation between two concepts-the arrows that link together concepts within and across levels of analysis. If theories are based on predictions of the relationship between two constructs, causal mechanisms constitute the "cogs and wheels" and "nuts and bolts" of theories (Elster, 1989; Whetten, 2002). ${ }^{2}$ An important motivation for the mechanism approach is that an acceptable explanation of Y can rarely be attained by simply referring to the causal relationship between $\mathrm{X}$ and $\mathrm{Y}$; this

\footnotetext{
${ }^{2}$ In management research, increased interest in causal mechanisms has also generated debate regarding their use for building theories, their analytical underpinnings (Mahoney, 2000; Ylikoski, 2013), epistemological and ontological sources (Durand \& Vaara, 2009), implications for temporal causality (Marquis et al., 2007), consequences for methodological and empirical designs (Miller \& Tsang, 2011), and other practical concerns for management research (Anderson et al., 2006; Weber, 2006). While these debates are important, our purpose is not to engage in them. Instead, we outline how mechanism-based frameworks can be fruitfully used in institutional analyses of entrepreneurship.
}

is known as the "black box problem." ${ }^{3}$ Contextualized research requires careful application of basic principles of multilevel research designs to account for aggregation issues and differences across separate levels of analyses (e.g., Chan, 1998; Gersick, 1991).

\section{THE BATHTUB MODEL AS AN ORGANIZING FRAMEWORK FOR ENTREPRENEURSHIP MECHANISMS}

The shortcomings identified above call for the incorporation of more comprehensive mechanisms into entrepreneurship research. To further diagnose the limitations and propose a way forward that integrates social groups at the meso level, we use the bathtub model as an organizing framework. The bathtub model was originally proposed by Coleman (1990) and explicated by Hedström and Swedberg (1998) to discuss theoretical mechanisms spanning macro and micro levels of analysis. Hedström and Swedberg's application of Coleman's bathtub urges scholars to focus on three types of mechanisms: (1) situational mechanisms (represented by $\mathrm{AB}$ in Figure 1) by which the macro environments in which actors are embedded—such as countries, regions, organizations, markets, fields, and networks—shape actors' opportunities, goals, and beliefs; (2) action-formation mechanisms (represented by BC) that explain how these opportunities, goals, and beliefs influence an actor's behavior; and (3) transformational mechanisms (represented by CD) that account for how the behavior of many actors jointly brings about both intended and unintended macro-level outcomes.

To illustrate the three bathtub mechanisms depicted in Figure 1, we use Shane and Venkataraman's (2000) individual-opportunity nexus framework. This example illustrates a potential chain of reasoning common in multilevel research. With entrepreneurial action as our outcome, the three individual-level mechanisms could be (1) changes in country-level fiscal regulations or social security policies that provide people with additional

\footnotetext{
${ }^{3}$ The mechanism movement in the social sciences is primarily concerned with the nature of explanations, not with causality or methods for establishing it. Not only do mechanisms help pinpoint causal relationships more accurately by emphasizing the context-dependent nature of relationships between explanans (explanations for a certain phenomenon) and an explanandum (the phenomenon to be explained), but they also provide a way for scholars to generalize their findings beyond their specific research contexts (Davis, 2006; Davis \& Marquis, 2005; Devinney, 2013; Hedström \& Ylikoski, 2010).
} 


\section{FIGURE 1}

\section{Original "Bathtub" Mechanisms Typology}

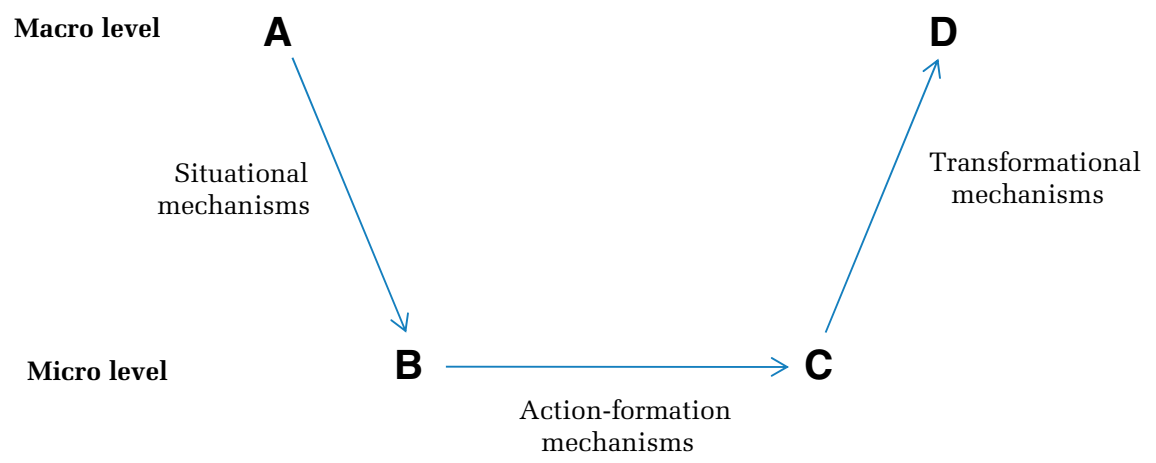

Source: Coleman (1987), Hedström and Swedberg (1998, p. 22).

economic assurances to pursue entrepreneurial opportunities (situational; $\mathrm{AB}$ ); (2) a propensity for risk-taking behaviors that encourages some people to take action on perceived opportunities (Caliendo, Fossen, \& Kritikos, 2009) (action-formation; BC); and (3) successful outcomes by these individuals over time that lead policy makers to enact new programs or tax schemes to encourage more entrepreneurial activity (transformational; CD).

While these examples place individuals within a broader social context and offer some explanations regarding entrepreneurial behavior, recall that Coleman's (1987) "macro-micro" problem occurs when scholars make inferences about a social system without fully integrating all of its component parts. We argue that most entrepreneurial research analyzes only a portion of the system, such as the individual-level influences we saw above, and so implicitly ignores higher- or lower-level contextual influences. As a result, we lack comprehensive models accounting for how macro-level conditions influence individuals (via the situational mechanism) and how individuals can in turn affect macro-level conditions (via the transformational mechanism). These limitations also restrict the possibility of meso-level influences and curtail our understanding of how individual actions might scale up and transform societies when individuals come together in meso-level structures (Aldrich \& Fiol, 1994; Ruef \& Lounsbury, 2007).

The basic application of the bathtub model as illustrated above allows us to establish a baseline for how this framework can clarify our thinking about the role of situational and transformational mechanisms. We now introduce the meso level of analysis to this original typology to expand the range of possible multilevel mechanisms (see Figure 2). Points A, $\mathrm{B}^{\prime}$, and $\mathrm{B}$ refer to the three levels of analysis (macro, meso, and micro) in which causal constructs can operate. Points $\mathrm{C}, \mathrm{C}^{\prime}$, and $\mathrm{D}$ refer to outcomes at the three levels. We argue that the meso level ( $\mathrm{B}^{\prime}$ and $\mathrm{C}^{\prime}$ ) is an important unit of analysis in its own right because entrepreneurial action can originate with networks and social groups (Ruef, 2010). Figure 2 shows examples of different causal pathways for situational, actionformation, and transformational mechanisms (e.g., $\left.\mathrm{AB}^{\prime}, \mathrm{B}^{\prime} \mathrm{C}^{\prime}, \mathrm{C}^{\prime} \mathrm{D}\right)$ and links all possible pathways among the three causal units. ${ }^{4}$ We display a range of research possibilities to distinguish mechanisms across different levels of analysis and to reveal potential shortcomings in how entrepreneurship researchers develop explanations. By tracing these causal pathways, we open up opportunities for theoretical advancements in underdeveloped areas of the framework. To assist with our explanations, we refer to the specific pathways using the reference points described in Figure 2.

Using the bathtub typology to classify mechanisms, we articulate entrepreneurial mechanisms in more systematic ways and show how the shortcomings of the two analytical traps - the ecological fallacy and the disaggregation bias-could be addressed. One way for researchers to avoid these traps is to interact more explicitly with concepts at different levels of analysis-macro, meso, and micro-to develop richer explanations for how theoretical constructs relate to each other, as we outlined in our proposed causal

\footnotetext{
${ }^{4}$ For ease of exposition, we assign the micro level to the individual level only (we revisit this assumption later in our discussion of future research opportunities). Besides simplifying our model applications to illustrate our arguments, attributing the micro level to individuals also enables us to leverage insights from existing findings of entrepreneurship research, most of which are at the individual level (Shepherd, 2011; Zahra \& Wright, 2011).
} 
FIGURE 2

\section{Multilevel Causal Mechanisms Framework}

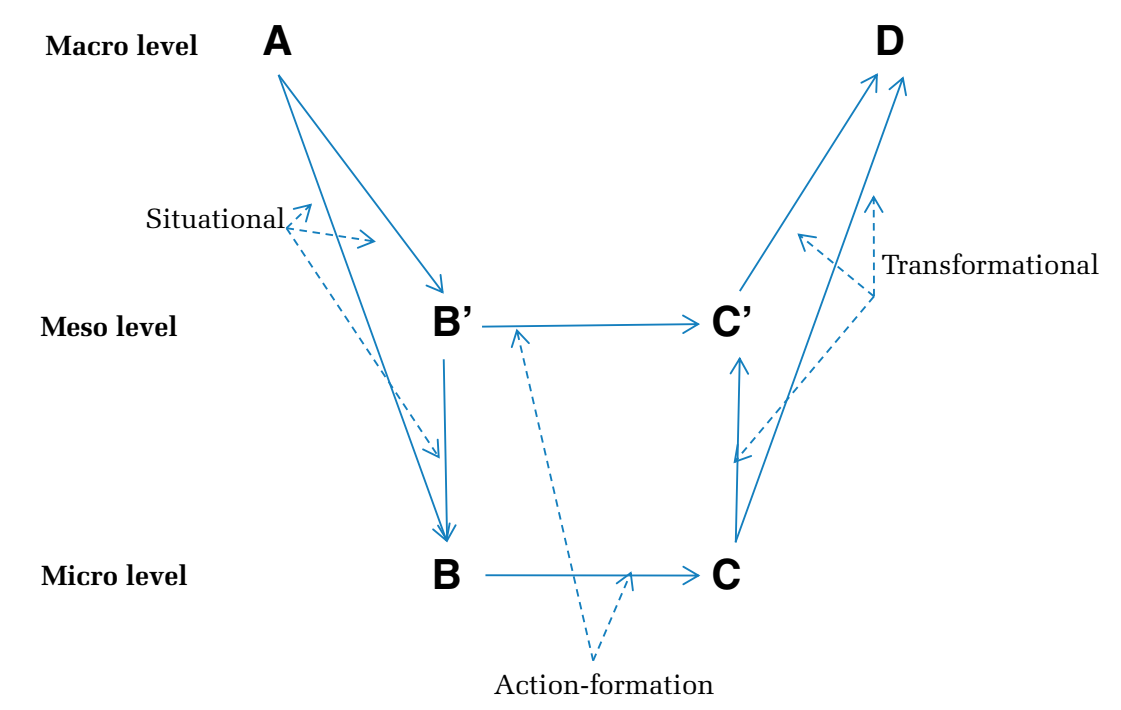

Notes:

Situational mechanisms include AB, AB', B'B, and AB'B.

Action-formation mechanisms include BC and B'C.

Transformational mechanisms include CC',C'D, CC'D, and CD.

mechanisms typology. By addressing the entire chain of situational, action-formation, and transformational mechanisms, scholars have a wider portfolio of explanations by which to describe entrepreneurial phenomena more accurately.

\section{EXPANDED BATHTUB MODEL APPLICATIONS TO ENTREPRENEURIAL MECHANISMS}

In entrepreneurship research, the fundamental question about why certain individual-level characteristics cause people to exploit promising business opportunities (e.g., Shane \& Venkataraman, 2000) can be recast from its common individuallevel action-formation mechanism (BC) to more comprehensive mechanisms involving either institutional (ABC) or relational ( $\left.\mathrm{AB}^{\prime} \mathrm{BC}\right)$ influences. Having outlined our conceptual framework, we now apply our more robust, macro-meso-micro bathtub model to two scenarios. The first scenario is a topdown mechanism involving countries-social groupsindividuals (Figure 2: $\mathrm{AB}^{\prime} \mathrm{BC}$ ). The second scenario is a bottom-up mechanism involving individuals-social groups-countries (BCC'D). (To conserve space, we focus the following exposition on the top-down scenario, as this represents the predominant type of causal mechanisms in entrepreneurship research. In the Discussion section we elaborate on various alternative bottom-up scenarios that could improve explanations of macro-level outcomes.) These scenarios reveal the value of integrating meso-level constructs into top-down and bottom-up mechanisms and begin to address the shortcomings of multilevel entrepreneurship research to date. Although many of the meso-level constructs are studied independently, these scenarios offer new opportunities to integrate these constructs into existing macromicro relationships to produce even deeper insights into how these multilevel relationships operate in the entrepreneurship domain. Moreover, these insights help avoid the two analytical traps-ecological fallacies and disaggregation biases-we described earlier.

\section{Top-Down Mechanisms (Country-Social Group-Individual)}

While existing research examining country-level institutional influences on individual entrepreneurial outcomes (Figure 2: ABC) has revealed important insights, we argue that the top-down entrepreneurial mechanisms along this left portion of the bathtub can be even more comprehensive if social-group, mesolevel structures are also integrated ( $\left.\mathrm{AB}^{\prime} \mathrm{BC}\right)$.

\section{Macro- to Micro-Level (ABC) Mechanisms}

Nearly all of the existing research on top-down entrepreneurial mechanisms ( $\mathrm{ABC}$ research) is about 
formal institutions-such as legal systems, tax policies, regulations, and property rights-influencing individual aspirations and entry in entrepreneurship (Henrekson \& Sanandaji, 2011). In these types of analyses, formal institutions have been most thoroughly studied because these are arguably the most uniformly explicated in the literature (North, 1990; Williamson, 2000) and also easier to identify and measure across contexts and over time (Andersson \& Henrekson, 2014). Generally speaking, institutions are depicted as having relatively stable macro-level attributes that determine the legal, normative, and cognitive scopes of action for actors in society (e.g., Acemoglu, Robinson, \& Woren, 2012; Lim, Oh, \& De Clercq, 2016; Scott, 2013). Institutional arrangements are also portrayed as important structures for facilitating economic exchange in society. From this principle, entrepreneurship researchers have pursued top-down investigations concerning macro-level structures influencing the micro-level actions of individuals or firms (Ruef \& Lounsbury, 2007). This research spans four major types of formal institutions: legal systems (Armour \& Cumming, 2008; Parker, 2007), tax policies (Carroll, HoltzEakin, Rider, \& Rosen, 2000; Gentry \& Hubbard, 2000; Kim, Lee, \& Reynolds, 2012), regulations (Braunerhjelm \& Eklund, 2014; Djankov, La Porta, Lopez-De-Silanes, \& Shleifer, 2002), and property rights (Autio \& Acs, 2010; Gans \& Persson, 2013).

\section{Meso-Level Integration Into ABC Research}

If social-group meso-level features were integrated into ABC research designs, what types of mechanisms would be relevant for entrepreneurship? One way to conceptualize the influence of social groups is to examine the role of social norms, widespread and established ideas about the proper way to behave (Granovetter, 1985). As social beings, people are naturally embedded in relational networks and are influenced by and contribute to social norms. The impact of these norms depends on the extent to which individuals are embedded in relationships with others, even if individual characteristics within those groups differ (Weiss \& Fershtman, 1998). But from social science research we know that groupbased social norms have a bearing on individual economic behavior. For example, residential peer effects from neighbors can have a strong and lasting influence on individuals throughout their life spans (Ioannides \& Loury, 2004; Mayer \& Jencks, 1989), and individuals often compare their job status and earnings with peers (Shue, 2013). In the labor market, group-based norms account for workplace absenteeism (Ichino \& Riphahn, 2004) and unemployment (Kolm, Hedström, \& Aberg, 2003). Studies have also shown links between social norms and entrepreneurship (Kacperczyk, 2013; Nanda \& Sørensen, 2010; Yang, Aldrich, \& Delmar, 2015). These social norms can differ regionally. For example, cultural groups throughout the African continent exhibit different forms of ubuntu-a strong form of collective behavior that instills loyalty and in-group support (Zoogah, Peng, \& Habte, 2015). Similarly, regional pace of life can promote a dominant work ethic that accounts for differences in entrepreneurial work effort (Vedula \& Kim, 2016).

\section{Macro-Meso-Micro-Level (AB' BC) Mechanisms}

We argue that norms produced by social groups can serve as mediating or moderating conditions between macro-level formal institutions and microlevel individual entrepreneurial outcomes (Figure 2: $\mathrm{AB}^{\prime} \mathrm{BC}$ ). This occurs primarily when social groups generate informal institutions, which have a strong influence on individual outcomes, especially when formal institutions are weak. If a social group or collective operates as a component of a mediating mechanism, the influence of formal institutions (such as laws and regulatory standards) operates through informal social groups so that these regulations are not directly enforced by authorities but become taken for granted and upheld through social practice. In contrast, if a social group or collective operates as a component of a moderating mechanism, the influence of formal institutions will exhibit a stronger or weaker influence on entrepreneurial action depending on the role of the social group or collective. Unlike the vast body of ABC research involving formal institutions, we lack studies on informal institutions, especially examining $\mathrm{AB}^{\prime} \mathrm{BC}$ situational mechanisms. This is a significant gap because research on institutions in economics, sociology, and political science widely recognizes informal institutions as major regulators of individual economic behavior (Granovetter, 2005; Greif, 2006; Williamson, 2000).

One helpful framework for differentiating formal and informal institutions is to treat the formal ones as public (via the state and enforced centrally) and the informal ones as private (via social groups and enforced informally) (Ingram \& Clay, 2000). We can apply this concept of private institutions using theory from the broader literature on social trust to derive additional insights about how meso-level social 
groups can influence entrepreneurial outcomes (Fukuyama, 1995; Knack \& Keefer, 1997; Putnam, 2000; Woolcock, 1998). We base our arguments on two prominent social-trust perspectives. First, according to Cook and her colleagues (2005, p. 2), an individual's trustworthiness becomes more evident through ongoing interactions; trust reflects "encapsulated interests" that are shared by both parties. This experience-based trust is "particular" in that it relies on the assumption that individuals within embedded relationships produce local norms as well as the sanctions to ensure that the norms are upheld (Coleman, 1987; Granovetter, 1985).

Voluntary membership organizations, such as professional associations and civic groups, provide people with opportunities to build relationships with other like-minded individuals. The level of involvement provides an indication of the extent to which people are linked together in organized groups in which trust-building conditions, such as reciprocity and positive emotions, can occur (Paxton, 1999). The particularized trust formed as a result of these relationships may be considered a private institution that operates with a centralized enforcement capacity; not only does the collective membership establish rules for the organization, they also sanction violators (Portes \& Sensenbrenner, 1993). For example, professional association members who fail to abide by their organization's code of conduct face ethical and practical consequences from their governing boards. Consequently, participation in voluntary organizations represents opportunities for people to develop and maintain trustworthy relationships with others; this has been referred to as the "communitarian" perspective in the social-trust literature (Woolcock \& Narayan, 2000, p. 229).

When membership in one organization overlaps with membership in another, both sets of participants can benefit from greater interorganizational contact, information access, and awareness of other like-minded people (Cornwell \& Harrison, 2004; Lee, 2007; Paxton, 1999). Moreover, depending on the extent to which overlap occurs, violators are likely to attract greater scrutiny or face sanctions from multiple constituencies (Coleman, 1957). In regions with higher levels of overlapping voluntary membership, we would expect particularized trust levels to be more evident than in regions with similar involvement but more isolated associations. We would expect that in regions with weak formal institutions, entrepreneurial action at the individual level will be influenced by the private institutions supported by these social groups (Welter \& Smallbone, 2003). For example, research on entrepreneurship in Russia after the fall of communism provides helpful details about meso-level mechanisms (Korzhov, 1999). During this era, individuals who were members of the Soviet Youth Communist Brigade (Komsomol) were more likely to exhibit entrepreneurial action. These members benefited from the shared intentions and overlapping networks among group members, especially by facilitating weak-tie introductions to external resource providers. Social norms in mesolevel groups can also be equally harmful to entrepreneurship, such as exhibited in the lasting effects of the cultural brigades of Mao's Cultural Revolution in the 1960s and Mugabe's youth brigades in Zimbabwe throughout the early 2000s (Tendi, 2011; Zhou \& Hou, 1999).

If the informal meso level were directly integrated into existing formal macro-level mechanisms, what would the outcomes look like? One possible outcome is when formal macro institutions are weak and informal meso institutions serve as their substitute. One exemplary illustration of this substitutionary role (Figure 2: $\mathrm{AB}^{\prime} \mathrm{BC}$ ) was reported by Estrin, Korosteleva, and Mickiewicz (2013), who showed that the negative influence of weak formal institutions, such as property-rights enforcement, corruption, and government size, was attenuated by entrepreneurs' own social networks. Similarly, Batjargal and colleagues (2013) reported in a crossnational study that entrepreneurs may benefit from structural holes produced by weak formal institutions in ways that can lead to higher venture growth. Rivera-Santos and colleagues (2014) demonstrated how ethnic identity plays a crucial role at the meso level in how African social ventures pursue their goals.

Another study by Kim and Li (2014) examined 30 emerging economies and the relationship between legal systems, social trust, and venture creation. They argued that people were less likely to start businesses in emerging economies with stronger legal systems, because legal protections favored established businesses over fledgling start-ups. Without formal protections benefiting them, aspiring entrepreneurs lacked the necessary assurancesprotections typically offered by the government through formal laws and functioning courts (Stinchcombe, 1965) — to invest time and resources into a potentially risky endeavor. However, with high levels of social trust, the negative relationship weakened such that social trust compensated for the lack of formal protections available to entrepreneurs. These studies are examples of how the integration of a meso-level 
construct can explicate the mechanisms influencing entrepreneurship more comprehensively.

\section{DISCUSSION}

In this section, we outline possibilities to apply, extend, or integrate our meso-level arguments to enhance our understanding of how entrepreneurial mechanisms operate in societies.

\section{Using Multilevel Models More Extensively}

Despite repeated calls for multilevel analyses integrating broader contextual and individual-oriented explanations, such analyses remain rare in the entrepreneurship literature (Davidsson \& Wiklund, 2001; Ruef \& Lounsbury, 2007; Shepherd, 2011; Zahra \& Wright, 2011). Any future research, however, requires high-quality, multilevel data to facilitate such analysis. Though a wealth of data exists on the effect of individual-level attitudes and socioeconomic resources, comprehensive testing of contextual explanations has been constrained by well-known challenges arising from the difficulty of social identification (Manski, 1990) and a lack of data necessary to fully specify multilevel models (Klein \& Kozlowski, 2000). Using multilevel methodologies offers a potential remedy to bridge these discrepancies between contextual and individual-centric explanations of entrepreneurship. When using our proposed framework to develop and test such models, researchers should situate the mechanisms within the proper levels of analysis (ABC, BCD, etc.). Further, care should be taken when using aggregated individuallevel data to explain macro-level outcomes. The use of individual-level perceptual data on social influences-such as studies on support from friends and family common in psychological explorations of entrepreneurship-can lead to inherently weak multilevel analysis because the association between an individual's perception of social influences and his or her actual behavior is individual-specific and may not "average out" when aggregated (Manski, 1990). Macro outcomes depend on both micro-level actions and interactions, and research focusing solely on macro-to-macro associations does not reveal which theoretical mechanisms determine the macro outcome. For example, research using perceptual data on individual entrepreneurs-such as in the GEM study-should use statistical techniques that account for the variance in individual perceptions when inferring group- or macro-level outcomes.

\section{Collecting Meso-Level Data}

While macro-level formal institutions are recognized at national, state, and other administrative or regional jurisdictions, meso-level informal institutions are subtler and may appear inconsistently within macro-level jurisdictions. From a research design perspective, institutional analyses of entrepreneurship can improve by identifying pertinent meso-level settings, such as workplaces (Nanda \& Sørensen, 2010), universities (Kacperczyk, 2013), and regions (Andersson \& Larsson, 2014; Dahl \& Sorenson, 2009). Once these data are assembled, scholars can employ network models or multilevel analytical tools to model effects at each level of analysis and accurately analyze uneven distributions (Börner et al., 2010). Such analyses are worthwhile for disentangling $\mathrm{A} \rightarrow \mathrm{D}$ correlates at the macro level and for detecting how differences in macro conditions affect individual entrepreneurial actions (ABC mechanisms) (Autio, Pathak, \& Wennberg, 2013).

When designing data-collection instruments, researchers should make an effort to capture multilevel information. For example, if individual-level data are collected on entrepreneurs, researchers should consider asking for additional information about the social groups in which they are involved (such as professional associations or civic groups) in ways that could be analyzed using appropriate multilevel statistical methods. Another approach is to use case studies to develop thick descriptions of how situational or transformational mechanisms operate in a particular entrepreneurial context.

\section{Investigating Bottom-Up Mechanisms}

As we alluded to earlier, the bathtub model offers a second set of mechanisms to integrate meso-level constructs. In this second scenario, on the right side of the bathtub model (Figure 2: BCC'D), we sketch out how these bottom-up mechanisms operate with an integrated meso-level component and discuss relevant research findings supporting our arguments. While the preponderance of entrepreneurship research is about situational and action-formation mechanisms, transformational mechanisms have not been fully specified; further research is required to understand more fully the impact of micro-level actions on macro-level outcomes (Figure 2: BCD). Although entrepreneurship has been associated with technological change (Schumpeter, 1934), economic growth (Wennekers \& Thurik, 1999), and employment 
growth (Coad, Daunfeldt, Johansson, \& Wennberg, 2014), the transformational mechanisms behind these outcomes are unclear-even as policy makers encourage entrepreneurship as a way to transform society (Spinosa, Flores, \& Dreyfus, 1999). Although some research has investigated portions of this pathway (BCD), this work has often occurred outside of the entrepreneurship domain (Padgett \& Powell, 2012). Modeling new applications of bottom-up mechanisms after studies from other disciplines will extend theories of entrepreneurial action.

Similar to our overview of top-down mechanisms in scenario 1, new investigations can occur in scenario 2 for both micro-to-macro (BCD) and micromeso-macro (BCC'D) mechanisms. For example, entrepreneurs who have started businesses in the "sharing economy" (for instance, Uber and Airbnb) have caused governments around the world to rapidly adapt their regulations in consideration of these new practices and business models. This direct micro-to-macro relationship (Figure 2: BCD) typically occurs in situations that prompt state regulatory interventions, such as when entrepreneurs operate at the boundary of the formal and informal economies, engage in contentious activities, find ways to develop activities that escape taxation, or directly challenge state-sponsored monopolies (Hiatt \& Sine, 2014; Monin \& Croidieu, 2012).

If the informal meso level were directly integrated into bottom-up mechanisms about entrepreneurial action, what would the outcomes look like? For example, professional and trade associations play a key mediating role for individual entrepreneurs who wish to advocate national-level regulatory changes (Aldrich \& Fiol, 1994; Barley, 2010; Scott, 2010). Sometimes, the meso-level structures are not formally organized, such as in the case of reform collectives that lobbied Chinese government agencies for more favorable business regulations ( $\mathrm{Li}$ et al., 2006; Nee \& Opper, 2012). These collectives helped challenge the status quo in the Chinese government through bottom-up efforts resulting in benefits for the entrepreneurs themselves.

\section{Invoking Temporality and Process Concepts}

The next possibility deals with the issue of temporality (e.g., Anderson et al., 2006; Gersick, 1991; McAdam et al., 2001). The tension between mere description and generalizable theories is particularly acute once time is taken into consideration, as time is unidirectional and it is unlikely that the exact same situation will repeat itself.
Scholars advocating for process theories have addressed the issue of temporality as a means of uncovering conceptual relationships and a successful alternative approach to regression-based variance research (Van de Ven \& Engleman, 2004). Much of the longitudinal or process research on entrepreneurship is located at a single level of analysis (e.g., individual, group, or national; Zahra and Wright, 2011). More nuanced insights into the situational macro-meso-micro or transformational micro-meso-macro pathways may result from invoking time and process explicitly into these linkages (Kim, Croidieu, \& Lippmann, 2016). Thus, with this approach, questions such as "How and why does the evolution of country-level formal institutions and social groups influence individual entrepreneurial action over time?" can be more thoroughly addressed. For example, Peng (2003) described a framework to understand how largescale macro-institutional change has consequences on entrepreneurial action. What is beneficial about his framework is that it explicitly addresses the long time frames during which institutional change occurs (such as transition economies adopting market reforms) and that these changes influence entrepreneurial action differently depending on the stage of development. Moreover, as we described earlier, in the absence of stable formal institutions during this transition, institutional voids may appear, requiring entrepreneurs or firms to mobilize in ways that can lead to additional macro-level reforms (Du, Kim, \& Aldrich, 2016; Ma, 2015; Nee \& Opper, 2012). Another example is the role of history and how social groups are imprinted by cohort or regional characteristics, which can influence entrepreneurial action over time (Lippmann \& Aldrich, in press). A focus on temporality and process often further illuminates the situational and transformational mechanisms at hand.

\section{Examining Policy Changes as Quasi-Experiments}

Entrepreneurship policy encompasses formal institutions such as legal systems, regulatory regimes, intellectual-property protection, and bankruptcy laws. While changes in these policies are used as gauges to assess the level or quality of entrepreneurship in society, informal institutions and other meso-level structures are difficult to manipulate through policy, and their slow-changing dynamics further complicate any practical interventions (Henrekson, 2005; Williamson, 2000). However, policy changes targeted for specific social groups 
and associations do occur regularly, such as in the case of school systems (Elert, Andersson, \& Wennberg, 2015). Moreover, policies may also be specifically designed for civic associations, charities, or resourceconstrained communities (Peredo \& Chrisman, 2006). In such cases, carefully designed studies could yield new insights into social-group influence on individual-level entrepreneurial outcomes and their subsequent impact back onto higher levels of analyses.

\section{Applying the Macro-Meso-Micro Bathtub Model at Different Levels}

Although we anchored our bathtub model to outline mechanisms at three specific levels of analysis (countries, social groups, and individuals), this was simply a matter of choice to provide clear applications of our multilevel arguments. By tracing the history of entrepreneurial thought, we know that the conceptualization of entrepreneurship has consistently varied over time across levels of analysis, implying a variety of multilevel perspectives on entrepreneurship (Hébert \& Link, 2007). By using the principle of aggregation (when a larger unit is created from a population of subunits), future research can adjust the macro or micro starting and ending points either upward or downward in levels of analysis (see Ruef and Lounsbury, 2007, and Scott, 2013, for a list of levels of analysis). Additionally, the meso level could be assigned to a different analytical structure besides social groups, as long as it does not violate the principle of aggregation between the chosen macro and micro starting points. Tables 1 and 2 offer other illustrative combinations and their corresponding studies.

As Tables 1 and 2 show, these illustrative multilevel studies represent the interplay between institutions and entrepreneurship as studied through a broader sociological, historical, and economic lens (Hwang \& Powell, 2005; North, 1990; Ruef \& Lounsbury, 2007; Thornton, 1999). Although classified in terms of top-down (Table 1) or bottom-up (Table 2) arguments to match our organizing framework, these studies actually contain elements of both (Barley \& Tolbert, 1997; Jing, Quinghua, \& Karlsson, 2017; Sine \& David, 2010; Tolbert et al., 2011) or offer an exchange-based understanding of economic action emphasizing mutual interplay (North, 1990). Moreover, studies using a neoinstitutional perspective have shown both field isomorphic pressures (influencing entrepreneurial action from the top down) and institutional






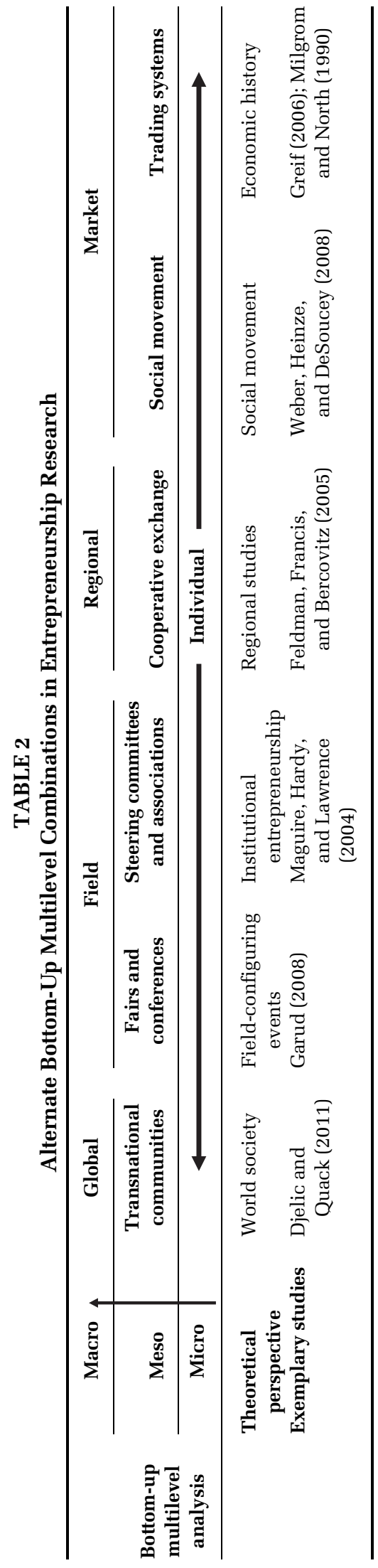

pressures (changing higher-level institutions from the bottom up). Future research can adapt our multilevel framework in ways that demonstrate the interplay of macro-meso-micro structures on entrepreneurial action.

\section{Alternative Theoretical Foundations for Multilevel Research}

While we focused on the bathtub model as our organizing framework, it is possible to use other theories to pursue multilevel research. One option is structuration theory-a line of reasoning that proposes a resolution to the long-standing agency-structure debate (Giddens, 1984). Structuration theory can be combined with institutional theory (e.g., Barley \& Tolbert, 1997) and other organizational and managerial theories (e.g., Orlikowski, 2000). However, there are trade-offs that need to be acknowledged. Structuration theory-being a theory founded on social interactions and rooted in assumptions about the composition of social structures-makes assumptions that constrain more comprehensive models of institutions and entrepreneurship. It does not allow for an easy separation of multiple levels beyond the macro and micro and requires that mechanisms start and end at the macro level. In contrast, the bathtub model provides more benefits for our objectives because it allows a more seamless integration of the individual, meso, and macro levels in ways that are fully compatible with the dominant framework of institutional analysis of entrepreneurship.

Despite its simplicity, the bathtub model has generated debate among social theorists regarding its internal features and applicability to understanding social systems and behavior more generally (Abell, Felin, \& Foss, 2014; Jepperson \& Meyer, 2011). We consider this debate to be outside the scope of our objectives. Instead, we simply reiterate that our use of the multilevel bathtub framework (represented in Figure 2) is a practical one because it aligns with the historical emphasis of entrepreneurship research at the micro (individual) and macro (societal) levels while easily allowing for the integration of meso-level insights, which have so far been under-theorized in entrepreneurship research (Aldrich \& Kim, 2007; Klotz et al., 2014; Ruef, 2010).

\section{CONCLUSION}

In summary, our article offers insights relevant to both academic researchers and policy makers. We emphasize the need for a better conceptual 
framework based on situational and transformational mechanisms to account for entrepreneurial phenomena. By highlighting the value of meso-level structures to enrich theories about entrepreneurial action, we encourage scholars to develop more robust and comprehensive theories. The prevalence of entrepreneurial action in groups, as well as the attitudes and behavioral norms toward entrepreneurship in those groups, constitutes the social fabric in the societies we study. In Durkheim's (1964, p. 288) words: "Because individuals form a society, new phenomena occur whose cause is association, and which, reacting upon the consciousness of individuals, for the most part shapes them. This is why, although society is nothing without individuals, each one of them is more a product of society than he is the author." By this, we do not portray entrepreneurs as "institutional dopes" mindlessly following whatever social norms they encounter (Powell \& Colyvas, 2008). Instead, we embrace the Durkheimian view where individuality and freedom are fundamental to economic actions and, in the long term, to economic development. This is the aspirational goal of policy makers for entrepreneurs to succeed and transform societies. A comprehensive understanding of entrepreneurial outcomes requires a multilevel approach that taps into the richness of meso-level studiesdiamonds that should no longer be hidden in plain sight.

\section{REFERENCES}

Abell, P., Felin, T., \& Foss, N. J. (2014). Microfoundations of social theory. A response to Jepperson and Meyer. Sociologica, 8(2), doi:10.2383/78819.

Acemoglu, D., Robinson, J. A., \& Woren, D. (2012). Why nations fail: The origins of power, prosperity and poverty. New York: Crown Business.

Aldrich, H. E. (2012). The emergence of entrepreneurship as an academic field: A personal essay on institutional entrepreneurship. Research Policy, 41(7), 1240-1248.

Aldrich, H. E., \& Fiol, C. M. (1994). Fools rush in? The institutional context of industry creation. Academy of Management Review, 19(4), 645-670.

Aldrich, H. E., \& Kim, P. H. (2007). Small worlds, infinite possibilities? How social networks affect entrepreneurial team formation and search. Strategic Entrepreneurship Journal, 1(2), 147-165.

Anderson, P. J. J., et al. (2006). Understanding mechanisms in organizational research reflections from a collective journey. Journal of Management Inquiry, 15(2), 102-113.

Andersson, M., \& Henrekson, M. (2014). Local competiveness fostered through local institutions for entrepreneurship (IFN Working Paper 1020). Stockholm: Research Institute of Industrial Economics (IFN).

Andersson, M., \& Larsson, J. P. (2014). Local entrepreneurship clusters in cities. Journal of Economic Geography, doi:10.1093/jeg/lbu049.

Armour, J., \& Cumming, D. (2008). Bankruptcy law and entrepreneurship. American Law and Economics Review, 10(2), 303-350.

Autio, E., \& Acs, Z. (2010). Intellectual property protection and the formation of entrepreneurial growth aspirations. Strategic Entrepreneurship Journal, 4(3), 234-251.

Autio, E., Dahlander, L., \& Frederiksen, L. (2013). Information exposure, opportunity evaluation, and entrepreneurial action: An empirical investigation of an online user community. Academy of Management Journal, 56(5), 1348-1371.

Autio, E., Pathak, S., \& Wennberg, K. (2013). Consequences of cultural practices for entrepreneurial behaviors. Journal of International Business Studies, 44(4), 334-362.

Baker, T., Gedajlovic, E., \& Lubatkin, M. (2005). A framework for comparing entrepreneurship processes across nations. Journal of International Business Studies, 36(5), 492-504.

Barley, S. R. (2010). Building an institutional field to corral a government: A case to set an agenda for organization studies. Organization Studies, 31(6), 777-805.

Barley, S. R., \& Tolbert, P. S. (1997). Institutionalization and structuration: Studying the links between action and institution. Organization Studies, 18(1), 93-117.

Batjargal, B., Hitt, M. A., Tsui, A. S., Arregle, J.-L., Webb, J. W., \& Miller, T. L. (2013). Institutional polycentrism, entrepreneurs' social networks, and new venture growth. Academy of Management Journal, 56(4), 1024-1049.

Beckman, C. M., \& Burton, M. D. (2008). Founding the future: Path dependence in the evolution of top management teams from founding to IPO. Organization Science, 19(1), 3-24.

Börner, K., et al. (2010). A multilevel systems perspective for the science of team science. Science Translational Medicine, 2(49), 1-5.

Braunerhjelm, P., \& Eklund, J. E. (2014). Taxes, tax administrative burdens, and new firm formation. Kyklos, 67(1), 1-11.

Burt, R. S. (2004). Structural holes and good ideas. American Journal of Sociology, 110(2), 349-399.

Caliendo, M., Fossen, F. M., \& Kritikos, A. S. (2009). Risk attitudes of nascent entrepreneurs: New evidence from an experimentally validated survey. Small Business Economics, 32(2), 153-167.

Campbell, J. L. (2004). Institutional change and globalization. Princeton, NJ: Princeton University Press. 
Carroll, R., Holtz-Eakin, D., Rider, M., \& Rosen, H. S. (2000). Income taxes and entrepreneurs' use of labor (NBER Working Paper No. w6578). Cambridge, MA: National Bureau of Economic Research.

Carter, N. M., Gartner, W. B., \& Reynolds, P. D. (1996). Exploring start-up event sequences. Journal of Business Venturing, 11(3), 151-166.

Cartwright, D., \& Zander, A. F. (1968). Group dynamics: Research and theory. New York: Harper \& Row.

Chan, D. (1998). Functional relations among constructs in the same content domain at different levels of analysis: A typology of composition models. Journal of Applied Psychology, 83(2), 234-246.

Coad, A., Daunfeldt, S.-O., Johansson, D., \& Wennberg, K. (2014). Whom do high-growth firms hire? Industrial and Corporate Change, 23(1), 293-327.

Coleman, J. S. (1957). Community conflict. Glencoe, IL: Free Press.

Coleman, J. S. (1987). Microfoundations and macrosocial behavior. In J. C. Alexander, B. Giesen, R. Münch, \& N. J. Smelser (Eds.), The micro-macro link (pp. 153-173). Los Angeles: University of California Press.

Coleman, J. S. (1990). Foundations of social theory. Cambridge, MA: Belknap Press.

Cook, K. S., Hardin, R., \& Levi, M. (2005). Cooperation without trust? New York: Russell Sage Foundation.

Cornwell, B., \& Harrison, J. A. (2004). Union members and voluntary associations: Membership overlap as a case of organizational embeddedness. American Sociological Review, 69(6), 862-881.

Dahl, M. S., \& Sorenson, O. (2009). The embedded entrepreneur. European Management Review, 6(3), 172-181.

Davidsson, P., \& Wiklund, J. (2001). Levels of analysis in entrepreneurship research: Current research practice and suggestions for the future. Entrepreneurship Theory and Practice, 25(4), 81-100.

Davis, G. F. (2006). Mechanisms and the theory of organizations. Journal of Management Inquiry, 15(2), 114-118.

Davis, G. F., \& Marquis, C. (2005). Prospects for organization theory in the early twenty-first century: Institutional fields and mechanisms. Organization Science, 16(4), 332-343.

De Castro, J. O., Khavul, S., \& Bruton, G. D. (2014). Shades of grey: How do informal firms navigate between macro and meso institutional environments? Strategic Entrepreneurship Journal, 8(1), 75-94.

Devinney, T. M. (2013). Is microfoundational thinking critical to management thought and practice? Academy of Management Perspectives, 27(2), 81-84.
Djankov, S., Ganser, T., McLiesh, C., Ramalho, R., \& Shleifer, A. (2010). The effect of corporate taxes on investment and entrepreneurship. American Economic Journal: Macroeconomics, 2(3), 31-64.

Djankov, S., La Porta, R., Lopez-De-Silanes, F., \& Shleifer, A. (2002). The regulation of entry. Quarterly Journal of Economics, 117(1), 1-37.

Djelic, M.-L., \& Quack, S. (2011). The power of “limited liability": Transnational communities and cross-border governance. Research in the Sociology of Organizations, 33, 73-109.

Drori, G. S., \& Yue, Y. (2009). The innovation centre: A global model for entrepreneurship in the era of globalization. International Journal of Entrepreneurship and Innovation, 10(3), 171-180.

Du, Y., Kim, P. H., \& Aldrich, H. E. (2016). Hybrid strategies, dysfunctional competition, and new venture performance in transition economies. Management and Organization Review, 12(3).

Durand, R., \& Vaara, E. (2009). Causation, counterfactuals, and competitive advantage. Strategic Management Journal, 30(12), 1245-1264.

Durkheim, E. (1964). The division of labor in society. New York: Free Press.

Eesley, C. E., \& Wang, Y. (2014). The effects of mentoring in entrepreneurial career choice (Research Paper). Boston: Boston University School of Management.

Elert, N., Andersson, F. W., \& Wennberg, K. (2015). The impact of entrepreneurship education in high school on long-term entrepreneurial performance. Journal of Economic Behavior \& Organization, 111, 209-223.

Elster, J. (1989). Nuts and bolts for the social sciences. Cambridge, UK: Cambridge University Press.

Estrin, S., Korosteleva, J., \& Mickiewicz, T. (2013). Which institutions encourage entrepreneurial growth aspirations? Journal of Business Venturing, 28(4), 564-580.

Feldman, M., Francis, J., \& Bercovitz, J. (2005). Creating a cluster while building a firm: Entrepreneurs and the formation of industrial clusters. Regional Studies, 39(1), 129-141.

Fukuyama, F. (1995). Trust: The social virtues and the creation of prosperity. New York: Free Press.

Gans, J. S., \& Persson, L. (2013). Entrepreneurial commercialization choices and the interaction between IPR and competition policy. Industrial and Corporate Change, 22(1), 131-151.

Garud, R. (2008). Conferences as venues for the configuration of emerging organizational fields: The case of cochlear implants. Journal of Management Studies, 45(6), 1061-1088. 
Gentry, W. M., \& Hubbard, R. G. (2000). Tax policy and entrepreneurial entry. American Economic Review, 90(2), 283-287.

Gersick, C. J. G. (1991). Revolutionary change theories: A multilevel exploration of the punctuated equilibrium paradigm. Academy of Management Review, 16(1), 10-36.

Giddens, A. (1984). The constitution of society: Outline of the theory of structuration. Berkeley, CA: University of California Press.

Goodin, R. E. (1998). The theory of institutional design. Cambridge, UK: Cambridge University Press.

Granovetter, M. (1985). Economic action and social structure: The problem of embeddedness. American Journal of Sociology, 91(3), 481-510.

Granovetter, M. (2005). The impact of social structure on economic outcomes. Journal of Economic Perspectives, 19(1), 33-50.

Greif, A. (2006). Institutions and the path to the modern economy: Lessons from medieval trade. Cambridge, UK: Cambridge University Press.

Hébert, R. F., \& Link, A. N. (2007). Historical perspectives on the entrepreneur. Foundations and Trends ${ }^{\circledR}$ in Entrepreneurship, 2(4), 261-408.

Hedström, P., \& Swedberg, R. (1998). Social mechanisms: An analytical approach to social theory. Cambridge, UK: Cambridge University Press.

Hedström, P., \& Ylikoski, P. (2010). Causal mechanisms in the social sciences. Annual Review of Sociology, 36(1), 49-67.

Henrekson, M. (2005). Entrepreneurship: A weak link in the welfare state? Industrial and Corporate Change, 14(3), 437-467.

Henrekson, M., \& Sanandaji, T. (2011). The interaction of entrepreneurship and institutions. Journal of Institutional Economics, 7(1), 47-75.

Hiatt, S. R., \& Sine, W. D. (2014). Clear and present danger: Planning and new venture survival amid political and civil violence. Strategic Management Journal, 35, 773-785.

Hwang, H., \& Powell, W. W. (2005). Institutions and entrepreneurship. In S. A. Alvarez, R. Agarwal, \& O. Sorenson (Eds.), Handbook of entrepreneurship research (pp. 201-232). Berlin: Springer.

Ichino, A., \& Riphahn, R. T. (2004). Absenteeism and employment protection: Three case studies. Swedish Economic Policy Review, 11, 95-114.

Ingram, P., \& Clay, K. (2000). The choice-within-constraints new institutionalism and implications for sociology. Annual Review of Sociology, 26(1), 525-546.

Ioannides, Y. M., \& Loury, L. D. (2004). Job information networks, neighborhood effects, and inequality. Journal of Economic Literature, 42(4), 1056-1093.
Jack, S. L. (2005). The role, use, and activation of strong and weak network ties: A qualitative analysis. Journal of Management Studies, 42(6), 1233-1259.

Jepperson, R., \& Meyer, J. W. (2011). Multiple levels of analysis and the limitations of methodological individualisms. Sociological Theory, 29(1), 54-73.

Jing, S., Quinghua, Z., \& Karlsson, T. (2017). Beyond red tape and fools: Institutional theory in entrepreneurship research 1992-2014. Entrepreneurship Theory and Practice, 41(4).

Kacperczyk, A. J. (2013). Social influence and entrepreneurship: The effect of university peers on entrepreneurial entry. Organization Science, 24(3), 664-683.

Kim, P. H., Croidieu, G., \& Lippmann, S. (2016). Responding from that vantage point: Field position and discursive strategies of legitimation in the early U.S. wireless telegraphy field. Organization Studies, 37(10). doi:0170840616634132.

Kim, P. H., Lee, C., \& Reynolds, P. D. (2012). Backed by the state: Social protection and starting businesses in knowledge-intensive industries. In J. Katz \& A. C. Corbett (Eds.), Advances in entrepreneurship, firm emergence and growth: Vol. 14, Entrepreneurial action (pp. 25-62). Bingley, UK: Emerald Group.

Kim, P. H., \& Li, M. (2014). Seeking assurances when taking action: Legal systems, social trust, and starting businesses in emerging economies. Organization Studies, 35(3), 359-391.

Kim, P. H., Longest, K. C., \& Aldrich, H. E. (2013). Can you lend me a hand? Task-role alignment of social support for aspiring business owners. Work and Occupations, 40(3), 211-247.

King, G. (2013). A solution to the ecological inference problem: Reconstructing individual behavior from aggregate data. Princeton, NJ: Princeton University Press.

Klein, K. J., \& Kozlowski, S. W. J. (2000). From micro to meso: Critical steps in conceptualizing and conducting multilevel research. Organizational Research Methods, 3(3), 211-236.

Klotz, A. C., Hmieleski, K. M., Bradley, B. H., \& Busenitz, L. W. (2014). New venture teams: A review of the literature and roadmap for future research. Journal of Management, 402(1), 226-255.

Knack, S., \& Keefer, P. (1997). Does social capital have an economic payoff? A cross-country investigation. Quarterly Journal of Economics, 112(4), 1251-1288.

Kolm, A.-S., Hedström, P., \& Aberg, Y. (2003). Social interactions and unemployment (Working Paper No. 2003:15). Uppsala, Sweden: IFAU - Institute for Evaluation of Labour Market and Education Policy. 
Korzhov, G. (1999). Historical and cultural factors of entrepreneurship re-emergence in post-socialist Ukraine. Polish Sociological Review, 128, 503-532.

Kroeber, A. L., \& Parsons, T. (1958). The concepts of culture and of social system. American Sociological Review, 23(5), 582-590.

Lee, C.-S. (2007). Labor unions and good governance: A cross-national, comparative analysis. American Sociological Review, 72(4), 585-609.

Lee, S. H., Yamakawa, Y., Peng, M. W., \& Barney, J. B. (2011). How do bankruptcy laws affect entrepreneurship development around the world? Journal of Business Venturing, 26(5), 505-520.

Levie, J., Autio, E., Acs, Z., \& Hart, M. (2014). Global entrepreneurship and institutions: An introduction. Small Business Economics, 42(3), 437-444.

Li, D. D., Feng, J., \& Jiang, H. (2006). Institutional entrepreneurs. American Economic Review, 96(2), 358-362.

Liljenström, H., \& Svedin, U. (2005). Micro, meso, macro: Addressing complex systems couplings. London: World Scientific.

Lim, D. S. K., Oh, C. H., \& De Clercq, D. (2016). Engagement in entrepreneurship in emerging economies: Interactive effects of individual-level factors and institutional conditions. International Business Review, 25(4), 933-945.

Lippmann, S., \& Aldrich, H. (in press). A rolling stone gathers momentum: Generational units, collective memory, and entrepreneurship. Academy of Management Review, doi:10.5465/amr.2014.0139.

Ma, D. (2015). Social belonging and economic action: Affection-based social circles in the creation of private entrepreneurship. Social Forces, 94(1), 87-114.

Maguire, S., Hardy, C., \& Lawrence, T. B. (2004). Institutional entrepreneurship in emerging fields: HIV/ AIDS treatment advocacy in Canada. Academy of Management Journal, 47(5), 657-679.

Mahoney, J. (2000). Strategies of causal inference in small$\mathrm{N}$ analysis. Sociological Methods \& Research, 28(4), 387-424.

Manski, C. F. (1990). The use of intentions data to predict behavior: A best-case analysis. Journal of the American Statistical Association, 85(412), 934-940.

Marquis, C., Glynn, M. A., \& Davis, G. F. (2007). Community isomorphism and corporate social action. Academy of Management Review, 32(3), 925-945.

Marquis, C., \& Lounsbury, M. (2007). Vive la résistance: Competing logics and the consolidation of U.S. community banking. Academy of Management Journal, 50(4), 799-820.
Mayer, S. E., \& Jencks, C. (1989). Growing up in poor neighborhoods: How much does it matter? Science, 243(4897), 1441-1445.

McAdam, D., Tarrow, S., \& Tilly, C. (2001). Dynamics of contention. Cambridge, UK: Cambridge University Press.

McMullen, J. S., \& Shepherd, D. A. (2006). Entrepreneurial action and the role of uncertainty in the theory of the entrepreneur. Academy of Management Review, 31(1), 132-152.

Milgrom, P. R., \& North, D. C. (1990). The role of institutions in the revival of trade: The law merchant, private judges, and the champagne fairs. Economics and Politics, 2(1), 1-23.

Miller, K. D., \& Tsang, E. W. K. (2011). Testing management theories: Critical realist philosophy and research methods. Strategic Management Journal, 32(2), 139-158.

Monin, P., \& Croidieu, G. (2012). The legitimating strategies of renegade organizations. M@n@gement, 15(3), 253-263.

Mullins, J. (2006). The new business road test: What entrepreneurs and executives should do before writing a business plan (2nd ed.). New York: Prentice Hall/ Financial Times.

Nanda, R., \& Sørensen, J. B. (2010). Workplace peers and entrepreneurship. Management Science, 56(7), 1116-1126.

Nee, V., \& Opper, S. (2012). Capitalism from below: Markets and institutional change in China. Cambridge, MA: Harvard University Press.

North, D. C. (1990). Institutions, institutional change, and economic performance. The political economy of institutions and decisions. Cambridge, UK: Cambridge University Press.

Orlikowski, W. J. (2000). Using technology and constituting structures: A practice lens for studying technology in organizations. Organization Science, 11(4), 404-428.

Padgett, J. F., \& Powell, W. W. (2012). The emergence of organizations and markets. Princeton, NJ: Princeton University Press.

Parker, S. C. (2007). Law and the economics of entrepreneurship. Comparative Labor Law \& Policy Journal, 28(4), 695-715.

Parker, S. C. (2008). The economics of formal business networks. Journal of Business Venturing, 23(6), 627-640.

Paxton, P. (1999). Is social capital declining in the United States? A multiple indicator assessment. American Journal of Sociology, 105(1), 88-127. 
Peng, M. W. (2003). Institutional transitions and strategic choices. Academy of Management Review, 28(2), 275-296.

Peredo, A. M., \& Chrisman, J. J. (2006). Toward a theory of community-based enterprise. Academy of Management Review, 31(2), 309-328.

Peterson, M. F., Arregle, J.-L., \& Martin, X. (2012). Multilevel models in international business research. Journal of International Business Studies, 43(5), 451-457.

Portes, A., \& Sensenbrenner, J. (1993). Embeddedness and immigration: Notes on the social determinants of economic action. American Journal of Sociology, 98(6), 1320-1350.

Powell, W. W., \& Colyvas, J. A. (2008). Microfoundations of institutional theory. In R. Greenwood, C. Oliver, R. Suddaby, \& K. Sahlin-Andersson (Eds.), SAGE handbook of organizational institutionalism (pp. 276-298). Thousand Oaks, CA: SAGE Publishing.

Putnam, R. D. (2000). Bowling alone: The collapse and revival of American community. New York: Simon \& Schuster.

Rivera-Santos, M., Holt, D., Littlewood, D., \& Kolk, A. (2014). Social entrepreneurship in sub-Saharan Africa. Academy of Management Perspectives, 29(1), 72-91.

Rotger, G. P., Gørtz, M., \& Storey, D. J. (2012). Assessing the effectiveness of guided preparation for new venture creation and performance: Theory and practice. Journal of Business Venturing, 27(4), 506-521.

Ruef, M. (2010). The entrepreneurial group: Social identities, relations, and collective action. Princeton, NJ: Princeton University Press.

Ruef, M., Aldrich, H. E., \& Carter, N. M. (2003). The structure of founding teams: Homophily, strong ties, and isolation among U.S. entrepreneurs. American Sociological Review, 68(2), 195-222.

Ruef, M., \& Lounsbury, M. (2007). Introduction: The sociology of entrepreneurship. In M. Ruef \& M. Lounsbury (Eds.), The sociology of entrepreneurship (pp. 1-32). Oxford, UK: JAI Press.

Saxenian, A. (1994). Regional advantage: Culture and competition in Silicon Valley and Route 128. Cambridge, MA: Harvard University Press.

Schumpeter, J. A. (1934). The theory of economic development: An inquiry into profits, capital, credit, interest, and the business cycle. Cambridge, MA: Harvard University Press.

Scott, W. R. (2010). Entrepreneurs and professionals: The mediating role of institutions. Research in the Sociology of Work, 21, 27-49.

Scott, W. R. (2013). Institutions and organizations: Ideas, interests, and identities. Thousand Oaks, CA: SAGE Publications.
Shane, S., \& Venkataraman, S. (2000). The promise of entrepreneurship as a field of research. Academy of Management Review, 25(1), 217-226.

Shepherd, D. A. (2011). Multilevel entrepreneurship research: Opportunities for studying entrepreneurial decision making. Journal of Management, 37(2), 412-420.

Shue, K. (2013). Executive networks and firm policies: Evidence from the random assignment of MBA peers. Review of Financial Studies, 26(6), 1401-1442.

Sine, W. D., \& David, R. J. (Eds.). (2010). Institutions and entrepreneurship (Vol. 21). Bingley, UK: Emerald.

Sorenson, O., \& Audia, P. G. (2000). The social structure of entrepreneurial activity: Geographic concentration of footwear production in the United States, 1940-1989. American Journal of Sociology, 106(2), 424-461.

Spinosa, C., Flores, F., \& Dreyfus, H. L. (1999). Disclosing new worlds: Entrepreneurship, democratic action, and the cultivation of solidarity. Cambridge, MA: MIT Press.

Stinchcombe, A. L. (1965). Social structure and organizations. In J. G. March (Ed.), Handbook of organizations (pp. 142-193). Chicago: Rand McNally.

Stinchcombe, A. L. (1991). The conditions of fruitfulness of theorizing about mechanisms in social science. Philosophy of the Social Sciences, 21(3), 367-388.

Tendi, B.-M. (2011). Robert Mugabe and toxicity: History and context matter. Representation, 47(3), 307-318.

Thornton, P. H. (1999). The sociology of entrepreneurship. Annual Review of Sociology, 25, 19-46.

Tolbert, P. S., David, R. J., \& Sine, W. D. (2011). Studying choice and change: The intersection of institutional theory and entrepreneurship research. Organization Science, 22(5), 1332-1344.

Van de Ven, A. H., \& Engleman, R. M. (2004). Event- and outcome-driven explanations of entrepreneurship. Journal of Business Venturing, 19(3), 343-358.

Vedula, S., \& Kim, P. H. (2016). The impact of the pace of life in U.S. cities on entrepreneurial work effort (Working Paper). Babson Park, MA: Babson College.

Vissa, B. (2010). Entrepreneurs' networking style and initiation of economic exchange. Organization Science, 23(2), 492-510.

Vissa, B. (2011). A matching theory of entrepreneurs' tie formation intentions and initiation of economic exchange. Academy of Management Journal, 54(1), 137-158.

Wasserman, N. (2012). The founder's dilemmas. Princeton, NJ: Princeton University Press.

Weber, K. (2006). From nuts and bolts to toolkits: Theorizing with mechanisms. Journal of Management Inquiry, 15(2), 119-123. 
Weber, K., Heinze, K. L., \& DeSoucey, M. (2008). Forage for thought: Mobilizing codes in the movement for grassfed meat and dairy products. Administrative Science Quarterly, 53(3), 529-567.

Weiss, Y., \& Fershtman, C. (1998). Social status and economic performance: A survey. European Economic Review, 42(3), 801-820.

Welter, F. (2011). Contextualizing entrepreneurship: Conceptual challenges and ways forward. Entrepreneurship Theory and Practice, 35(1), 165-184.

Welter, F., \& Smallbone, D. (2003). Entrepreneurship and enterprise strategies in transition economies: An institutional perspective. In D. A. Kirby \& A. A. Watson (Eds.), Small firms and economic development in developed and transition economies: A reader (pp. 95-114). Farnham, UK: Ashgate Publishing, Ltd.

Wennekers, S., \& Thurik, R. (1999). Linking entrepreneurship and economic growth. Small Business Economics, 13(1), 27-56.

Whetten, D. A. (2002). Modelling-as-theorizing: A systematic methodology for theory development. In D. Partington (Ed.), Essential skills for management research (pp. 45-71). London: SAGE Publications.

Williamson, O. E. (1973). Markets and hierarchies: Some elementary considerations. American Economic Review, 63(2), 316-325.

Williamson, O. E. (1998). The institutions of governance. American Economic Review, 88(2), 75-79.

Williamson, O. E. (2000). The new institutional economics: Taking stock, looking ahead. Journal of Economic Literature, 38(3), 595-613.

Woolcock, M. (1998). Social capital and economic development: Toward a theoretical synthesis and policy framework. Theory and Society, 27(2), 151-208.

Woolcock, M., \& Narayan, D. (2000). Social capital: Implications for development theory, research, and policy. World Bank Research Observer, 15(2), 225-249.

Yang, T., Aldrich, H. E., \& Delmar, F. (2015). Forged in the heat of battle: Small and young organizations as incubators of entrepreneurship (Working Paper). Durham, NC: Duke University.

Ylikoski, P. (2013). Causal and constitutive explanation compared. Erkenntnis, 78(2), 277-297.

Zahra, S. A., \& Wright, M. (2011). Entrepreneurship's next act. Academy of Management Perspectives, 25(4), 67-83.

Zhou, X., \& Hou, L. (1999). Children of the cultural revolution: The state and the life course in the People's Republic of China. American Sociological Review, 64(1), 12-36.

Zoogah, D., Peng, M., \& Habte, W. (2015). Institutions, resources and organizational effectiveness in Africa. Academy of Management Perspectives, 29(1), 7-31.



Phillip H. Kim (pkim1@babson.edu) is an associate professor of entrepreneurship at Babson College. His research examines how founders launch, establish, and grow their nascent firms in emergent fields. His insights on these themes have been published in various entrepreneurship and management journals.

Karl Wennberg (karl.wennberg@liu.se) is a professor of management and deputy director of the Institute for Analytical Sociology at Linköping University in Sweden. His work focuses broadly on entrepreneurship, organizational change, and the macro-level implications of organizational dynamics.

Grégoire Croidieu (Gregoire.CROIDIEU@grenoble-em.com) is an associate professor at Grenoble Ecole de Management in France. His research combines institutional theory and entrepreneurship and focuses on the legitimation processes that shape the emergence and historical evolution of fields and organizations. He has authored papers on related topics in organization theory and management journals. 
Copyright of Academy of Management Perspectives is the property of Academy of Management and its content may not be copied or emailed to multiple sites or posted to a listserv without the copyright holder's express written permission. However, users may print, download, or email articles for individual use. 